\title{
Comparative Fiscal Response Effects of Debt Relief: an Application to African HIPCs
}

Danny Cassimon (danny.cassimon@ua.ac.be)

Bjorn Van Campenhout, Institute of Development Policy and Management (IOB), University of Antwerp, Belgium 


\section{Acknowledgements}

The authors wish to extend their particular thanks to Renato Flôres, George Mavrotas and Peter Nunnenkamp for their comments on an earlier draft of the paper, and to all involved AFD staff for their meticulous reviewing, handling and preparation of the manuscript.

\section{Disclaimer}

The analysis and conclusions of this document are those of the authors. They do not necessarily reflect the official position of AFD or its partner institutions.

Director of the publication: Jean-Michel SEVERINO

Editorial director : Robert PECCOUD

ISSN 1954-3131 - Registration of copyright: March 2008

(C) AFD 2008

Keyboarding/layout: Anne-Elizabeth COLOMBIER

(C) AFD Working Paper $\mathbf{N}^{\circ} \mathbf{6 3}$ - Comparative Fiscal Response Effects of Debt Relief - an Application to African HIPCs 
Contents

\begin{tabular}{|c|c|c|}
\hline & Abstract & 4 \\
\hline & Introduction & 5 \\
\hline 1. & The Relative Importance of HIPC and MDRI Debt Relief in the Budget & 7 \\
\hline 2. & Modeling Fiscal Response Analysis of Aid and Debt Relief & 12 \\
\hline 3. & An Application to African HIPC Countries & 14 \\
\hline 4. & Conclusions & 18 \\
\hline
\end{tabular}

(C) AFD Working Paper $\mathbf{N}^{\circ} \mathbf{6 3}$ - Comparative Fiscal Response Effects of Debt Relief - an Application to African HIPCs 


\section{Abstract}

As part of the efforts of the international donor community to scale up aid to Africa, substantial debt relief has been granted in recent years through the Heavily Indebted Poor Countries (HIPC) Initiative and its successor, the Multilateral Debt Relief Initiative (MDRI). This paper tries to assess, for a sample of 24 African countries that have at least reached decision point status in the HIPC Initiative, to what extent this debt relief has created fiscal space in recipient country budgets, and what, on average, the actual fiscal response effects have been, relative to other types of aid. Inspired by the fiscal response literature, we model public finance behavior as a system of structural equations and estimate the reduced form parameters in a Vector Autoregressive (VAR) framework. In general, we are unable to find evidence that substantiates the worries that debt relief might provoke no or even perverse fiscal responses. On average, debt relief affects public finance behavior in a desired way, with effects being most similar to those of its most direct substitute, program grants.

Keywords: HIPC, debt relief, fiscal response, aid effectiveness. JEL codes: F34, F35, O11, O19 


\section{Introduction}

During the last decade, reduction or outright cancellation of outstanding external debt of low-income developing countries to bilateral and multilateral donors has become all the rage. The Heavily Indebted Poor Countries (HIPC) Initiative was launched in 1996 to reduce the debt stock of a specific set of poor, debt-ridden countries to a sustainable level; it was enhanced in 1999 to provide deeper debt relief and more explicit poverty reduction focus by linking it to the Poverty Reduction Strategy Paper (PRSP) process. Its successor, the Multilateral Debt Relief Initiative (MDRI), launched in 2005 at the G8 Gleneagles Summit, aims at going beyond HIPC debt reduction by canceling the full remaining (post-HIPC) debt stock owed to the most important multilateral creditors for this same set of countries. The fact that debt relief is high on the agenda again is largely due to the strong civil society and public opinion support it enjoys, both in the North and the South. From a moral point of view, it is indeed questionable whether countries should collect debts from people who are dirt poor. But there is also a psychological factor: it seems people in rich countries find it easier to forgo debt repayment than to scale up aid using tax money. The fact that the occasional rock star joins in obviously helps to get the deal through.

Apart from the moral arguments, there are also economic arguments in favor of debt relief. First, debt relief can free up public resources that would otherwise have been earmarked for debt service, i.e. provide "fiscal space" (Heller, 2005). Second, there is the well-known debt overhang theory that states that unsustainable levels of debt may lead to sub-optimal investment in the private sector for fear of future taxation. The debt overhang effect also plays in the public sphere: high debt service obligations may reduce the incentive of debtors to engage in policy reforms that raise revenues available for debt service, since part of the addi- tional revenues accrue to the creditor (Krugman 1988). Thirdly, to the extent that donors may succeed in securing development aid budget increases thanks to the use of debt relief (e.g. because of strong public opinion support for debt relief), debt relief may transform into fast-disbursing aid effectively scaling up the aid volume. Finally, it may be the case that debt relief can be engineered to be an aid modality supplied with more donor harmonization, and/or more effective types of conditionality.

However, the above does not automatically mean that debt relief is superior to other modalities of development aid, such as project or program grants or loans, or technical assistance. When we acknowledge that debt relief is just another aid instrument at the disposal of donors (Berlage et al. 2003), we should also carefully think about the relative effectiveness of debt relief. In other words, the question we should ask ourselves is which instrument is most efficient in attaining its goal.

The present paper explores the relative effectiveness of debt relief for a panel of African HIPC countries. However, we will not relate debt relief directly to outcome variables like poverty or income. We want to open up the black box and study the channels through which aid reduces poverty. One of the important features of aid is that most of it is given to governments, and as such is "budgetized" in some way, a feature that will greatly influence its effect on outcome variables ${ }^{1}$. Aid adds to the resources available in the budget, and can potentially be used for a diversified set of

${ }^{1}$ And even when aid is off-budget, it can provoke a fiscal response especially due to aid fungibility effects. 
purposes, ranging from increased spending, to fiscal deficit reduction or even domestic revenue mobilization; in other words, it causes fiscal (response) effects. This is definitely the case for debt relief, as debt service has to be paid out of the budget. In this paper, we will model the public sector response to changes in aid in a Vector Autoregressive (VAR) framework. Hence, we agree with McGillivray and Morrisey (2000) that identifying the (intertemporal) fiscal effects of aid is a prerequisite to understanding the macroeconomic effectiveness of aid.

Note that in this paper we are not so much interested in the individual HIPC country fiscal response to debt relief, but rather focus on a more "systemic" fiscal response of the (African) HIPCs. Indeed, we want to draw policy conclusions that move beyond the individual country context, and contribute to a discussion at the global policy level on the desirability of more (global initiatives on) debt relief and the comparative impact of debt relief relative to other aid modalities. As such, we perform a panel VAR analysis.

This article is organized as follows. The first section describes some factual observations and historical overview regarding the overall importance of (enhanced) HIPC and MDRI debt relief in the budget of recipient African HIPCs, relative to other aid interventions as well as other key budget categories. The next section briefly discusses the model we will use to assess the relative effectiveness of debt relief. Section three presents the results of the application of this model to a panel of African HIPC countries. The last section concludes and discusses policy issues. 


\section{The Relative Importance of HIPC and MDRI Debt Relief in the Budget}

In this section, we briefly describe some stylized facts on the relative importance of debt relief and other aid in African countries' budgets, in comparison with other key budget categories, and their evolution over time. More specifically, the analysis will be carried out looking at a sample of 24 African HIPCs that have reached at least decision point status in the HIPC Initiative ${ }^{2}$. For this purpose, a database of fiscal variables was constructed, using data for these countries taken essentially from the budgetary data presented in IMF country reports, such as article IV reports, PRGF reviews, as well as HIPC decision and/or completion point documents. To the extent possible, data are gathered spanning the period 1991-2006. For most countries, the data allow us to disaggregate aid into project and program loans and grants, as well as debt relief components. For reasons explained later, instead of focusing on the full debt relief, we only deal with (Enhanced) HIPC debt relief, and, for 2006, its successor the MDRI.

Table 1 provides an overview of the evolution of the main budgetary components, including HIPC and MDRI debt relief, expressed in percentage of GDP. We present here the "average" situation for our sample of countries ${ }^{3}$, by calculating the (unweighted) means. The presentation here rearranges the conventional budget format, focusing on categories that are important from the perspective of our analysis only, while still allowing for a closed budget representation.

\footnotetext{
${ }^{2}$ Benin, Burkina Faso, Burundi, Cameroon, Chad, DRC, Ethiopia, Gambia, Ghana, Guinea, Guinea-Bissau, Madagascar, Malawi, Mali, Mauritania, Mozambique, Niger, Rwanda, Sao Tome \& Principe, Senegal, Sierra Leone, Tanzania, Uganda and Zambia.

${ }^{3}$ Individual country tables are not reported, but are available from the authors on request.
} 
Table 1. Evolution of main budgetary categories for the average African HIPC (\% of GDP)

\begin{tabular}{|c|c|c|c|c|c|c|c|c|c|c|c|c|c|c|c|c|}
\hline & 1991 & 1992 & 1993 & 1994 & 1995 & 1996 & 1997 & 1998 & 1999 & 2000 & 2001 & 2002 & 2003 & 2004 & 2005 & 2006 \\
\hline Domestic revenues [a] & 14.70 & 13.14 & 13.68 & 13.58 & 12.97 & 13.35 & 13.51 & 13.34 & 14.51 & 15.63 & 14.80 & 14.60 & 15.23 & 15.82 & 16.33 & 16.99 \\
\hline Primary current spending [b] & 11.07 & 11.31 & 12.49 & 12.96 & 12.75 & 11.14 & 11.14 & 11.26 & 12.02 & 12.95 & 13.94 & 13.63 & 14.25 & 14.17 & 14.19 & 15.06 \\
\hline Government investment [c] & 7.47 & 7.78 & 9.02 & 8.80 & 8.63 & 9.34 & 12.10 & 8.83 & 10.57 & 10.75 & 10.92 & 8.41 & 9.37 & 10.07 & 9.00 & 9.28 \\
\hline Primary balance w/o grants [d] & -3.85 & -5.95 & -7.83 & -8.18 & -8.42 & -7.12 & -9.74 & -6.75 & -8.08 & -8.06 & -10.06 & -7.44 & -8.39 & -8.43 & -6.86 & -7.35 \\
\hline Net domestic borrowing [e] & -0.91 & -1.70 & -0.18 & -0.15 & 0.51 & 0.36 & -1.22 & 1.54 & 0.88 & 1.81 & 2.27 & 0.83 & 1.91 & 1.09 & -1.03 & 0.15 \\
\hline Debt service due (+other) [f] & 4.54 & 2.50 & 3.28 & 4.91 & 4.22 & 3.91 & 2.49 & 3.92 & 4.10 & 5.56 & 4.86 & 3.78 & 4.65 & 4.92 & 3.26 & 3.91 \\
\hline
\end{tabular}

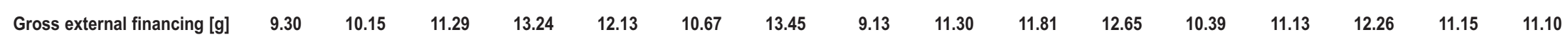

$\begin{array}{rllllllllllllllll}\text { project } & 5.89 & 6.85 & 7.64 & 7.57 & 7.54 & 7.71 & 9.66 & 6.68 & 8.33 & 8.08 & 7.63 & 6.05 & 6.57 & 6.82 & 6.09 & 6.16 \\ \text { grant } & 2.84 & 3.41 & 4.27 & 3.84 & 3.94 & 4.13 & 5.50 & 3.13 & 4.22 & 4.44 & 4.45 & 3.49 & 4.01 & 3.60 & 3.43 & 3.38\end{array}$

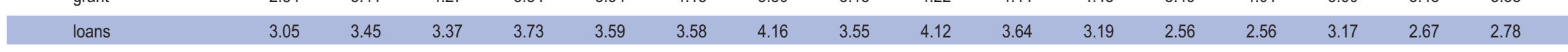

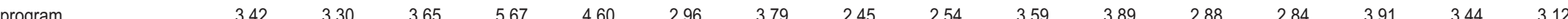

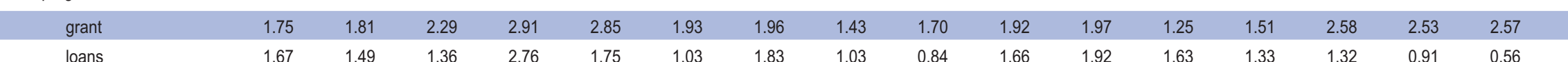

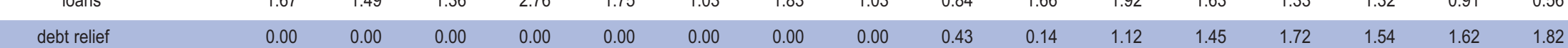

$\begin{array}{lllll}0.00 & 0.00 & 0.00 & 0.00 & 0.00 \\ 0.00 & 0.00 & 0.00 & 0.00 & 0.00\end{array}$

$\begin{array}{ccccccccccccccccc}\text { in grant s } & 0.00 & 0.00 & 0.00 & 0.00 & 0.00 & 0.00 & 0.00 & 0.00 & 0.29 & 0.06 & 0.67 & 0.93 & 1.03 & 0.98 & 0.92 & 0.97 \\ \text { other } & 0.00 & 0.00 & 0.00 & 0.00 & 0.00 & 0.00 & 0.00 & 0.00 & 0.13 & 0.08 & 0.45 & 0.52 & 0.69 & 0.55 & 0.70 & 0.41 \\ \text { MDRI } & 0.00 & 0.00 & 0.00 & 0.00 & 0.00 & 0.00 & 0.00 & 0.00 & 0.00 & 0.00 & 0.00 & 0.00 & 0.00 & 0.00 & 0.00 & 0.43\end{array}$

Source: Author's calculations on the basis of IMF country documents. The table is constructed as a balanced budget. As such, $[d]=[a]-[b]-[c]$, and $[d]+[e]-[f]=-[g]$. 


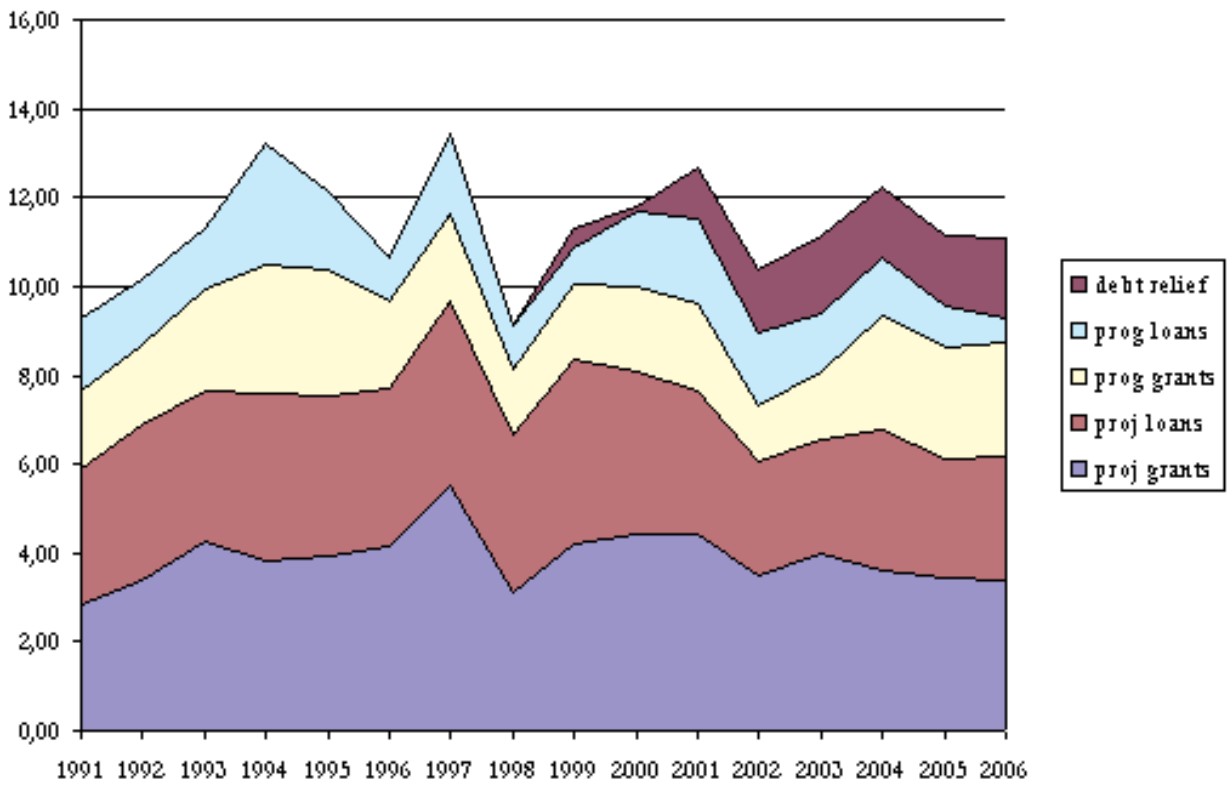

The lower part of the table presents total gross external (aid) financing of the budget, disaggregated in its (project and program) loan and grant components over time, as well as (enhanced) HIPC and MDRI debt relief. This is also shown in Figure 1.

Before interpreting the table, it is important to discuss somewhat more extensively the debt relief data needed to construct it, and the paper in general. Debt relief, including HIPC Initiative debt relief, cannot always be read immediately from the budgetary information provided by IMF reports and different countries use different ways of accounting for debt relief in their budget (see IMF and IDA (2001) for a more detailed treatment of this issue). HIPC debt relief has two major components: multilateral and bilateral debt relief. The multilateral part is typically accounted for as a grant and usually in a separate budget line ${ }^{4}$. Bilateral debt relief is often much more difficult to trace, as debt service is often presented in the budget as part of "exceptional finance", or even net of debt relief, or without a separate budget line indicating the amount of debt relief embedded. However, within the framework of completion point triggers and the PRSP, the IMF (and the World Bank) is usually tracking very closely the amount of HIPC debt relief actually gran- ted, which means that total HIPC debt relief is available, e.g. added as memorandum items to the country budgetary tables. As such, for HIPC debt relief, it is in general feasible to construct a variable representing the total annual debt service relief resulting from the HIPC Initiative. This figure is added in Table 1 (and Figure 1), including singling out the grant component. The same exercise cannot be done for pre-HIPC debt relief, as public data available in the IMF documents typically show the stock effect of debt relief, not the annual debt service relief resulting from it.

The table clearly shows that the impact of HIPC debt service relief should not be overestimated: on average it amounts to about $1.5 \%$ of GDP; in 2006 , MDRI adds about $0.5 \%$ to this. Relative to other aid components, it is quite small, but it does succeed in "scaling up" total gross external financing in the most recent years.

${ }^{4}$ As such, HIPC debt relief in the form of grants has to be deducted from the amount of aid given in the form of grants, so grant figures in our database are of course net of HIPC debt relief grants. 
This could be considered as the "accounting" (or "virtual") fiscal space effect of debt relief. However, one dollar of debt relief is not necessarily equivalent to one dollar of additional grant aid: this is the case only to the extent that debt would have been serviced in the absence of debt relief intervention. As such, whether debt relief creates fiscal space in a direct way in practice depends on whether the debt that is relieved would have been serviced in the absence of the debt relief intervention; in more broader terms, it can be measured by the difference between debt service paid (instead of due) before and debt service due after debt relief.

So will the HIPC Initiative create fiscal space in practice? The specific HIPC record is likely to be mixed: apart from being very different between recipient countries, more structurally we can state that the prime focus of the HIPC debt relief initiative was to wipe out the unsustainable part of external debt, and as such, it is unrealistic to assume that it creates a lot of fiscal space. Moreover, this issue was acknowledged explicitly as in each HIPC country, it was precisely determined what part of the total HIPC debt relief had to be "budgetized", i.e. had to be compensated in some way as additional spending, a reduction of net domestic borrowing etc. As this part is typically accounted for as grants in the recipient country budget, in our table, the grant element of debt relief, averaging around $1 \%$ of GDP, can be used as a very rough proxy for the direct fiscal space created by HIPC debt relief.

HIPC Initiative debt relief is now supplemented by MDRI debt relief, which follows largely the same logic and budgetary accounting treatment. As the MDRI was implemented only in 2006, MDRI debt relief occurs only in the final year of our database. Again, we account for the annual debt service gains of MRDI, not for the stock reduction. There is however one major potential difference between the (fiscal space) effects of MDRI, versus those of HIPC debt relief: MDRI debt relief, which is by nature additional relief for countries that had already regained debt sustainability under the HIPC Initiative, should in principle create direct fiscal space effects approaching a one-for-one basis, as it can be assumed that the debt relieved through MDRI would have been fully serviced otherwise.
Luckily, however, the full fiscal response effect of debt relief will most likely not be restricted to this real direct fiscal space effect for a number of reasons. First of all, debt relief may also impact debt overhang, with its associated structural lower economic growth outcome. Ceteris paribus, removal of debt overhang by debt relief, may lead to a series of associated fiscal response effects, such as an increase in public investment. And over time, through the impact on private investment and ultimately on higher economic growth, it may lead to increased domestic revenue mobilization in absolute terms. Again here, the type of debt relief may matter: (repeated) small amounts of debt relief may not trigger a regime shift in the economy out of a low-investment, lowgrowth debt overhang regime (Bulow and Rogoff, 1991), for which a substantial, one-off debt overhang elimination operation, such as that envisaged by HIPC debt relief, is necessary.

Regarding debt relief, an additional response effect might be at play. Several studies (e.g. Pack and Pack, 1993; McGillivray and Ouattara, 2005) have shown that recipient country governments ultimately used a large part of aid for debt servicing, which is a form of aid fungibility. Moreover, Birdsall et al., (2003) have convincingly shown that donors also engaged in "defensive" lending, providing relatively more aid to debt-ridden countries. Again debt relief might refrain governments from engaging in aid fungibility, and donors from disbursing aid for these 'defensive' purposes. Both cases may make all aid granted to the particular recipient country more effective.

As such, fiscal response analysis should look at full (budgetary) aid flows, including the effect of debt relief on other aid interventions. It is not a priori clear what the sign of the effect would be. On the one hand, fungibility may also be at play at the donor level, when the donor granting debt relief is at the same time reducing its efforts on other aid interventions (in the same recipient country). On the other hand, as the aid effectiveness literature has shown that aid is more effective once the debt overhang situation in a country is resolved, it is rational for donors to extend more aid after debt relief. Again, determining the sign of the relationship, and its intertemporal evolution, is ultimately an empirical case. 
Finally, the fiscal response effects that are linked to earmarking, conditionality and monitoring may be even more important, especially in the case of HIPC debt relief. It is well known that the HIPC Initiative has come about with a heavy and diversified portfolio of conditionality, including not only broad macroeconomic and structural reform conditionality through the conventional IMF program conditionality (typically embedded through a Poverty Reduction and Growth Facility, PRGF), but also with broad poverty focus through the PRSP, additional specific structural completion point triggers, and country-specific tracking mechanisms to monitor the use of HIPC debt savings ${ }^{5}$. In doing so, donors want to make sure that the (real) fiscal space created is used for activities that target poverty reduction. Overall, the HIPC Initiative has allowed focuses on broad earmarking, enabling debt relief to be used for a broad range of purposes, according to the priorities of the recipient country government, as determined in the PRSP, and reflected in a Medium-Term Fiscal Framework (MTFF) and the budget. The use of debt relief savings ranges from additional social sector and basic infrastructure spending, to reducing domestic debt, or merely reducing the fiscal deficit.

All these features have in theory potentially large additional fiscal response effects. What may cause the full fiscal space created not to be used for the desired purpose in the end, and what hampers the realization of the straightforward fiscal response effects? This can be due to actions by both the donor, as well as the recipient government.

From the recipient country government side, aid fungibility may be at play. Aid can be defined as (partly) fungible to the extent that the recipient government is able to circumvent this by reducing its own budgetary efforts in a similar way, effectively enabling their use for other purposes (undesired by the donor) ${ }^{6}$. Aid effort may substitute for domestic resource mobilization, as when the fiscal response of the recipient government to an increase in aid is to lower domestic taxation effort, or it may trigger expenditure shifting, such as sectoral fungibility where aid intended to be spent in a given sector (say health) provokes a reduction of the recipient government's own effort in that sector. But shifts can refer to broader categories of the budget, with aid ultimately being used for debt servicing, or reducing the fis- cal deficit and/or domestic borrowing. In case aid fungibility is indeed a severe problem, donors may wish to look for aid instruments and modalities that limit as much as possible this aid fungibility.

But fiscal space effects may also be constrained by the donor, typically through the same conditionality. Broad IMF program conditionality (including HIPC-specific conditionalities that need to be fulfilled in order to reach the HIPC completion point, the so-called completion point triggers) has shown to be potentially restrictive in effectively using the fiscal space created. To give one example, Weeks and McKinley (2006), argue that in the case of Zambia, HIPC debt relief had a negative effect on fiscal space, mainly due to expenditure and other ceilings in the IMF program. Also, micro-earmarking of the utilization of funds, through counterpart funds, using separate project monitoring units (PMU) that operate parallel to recipient country public finance management systems may hamper the effective use of funds, as shown by De Groot et al. (2003).

As such, the upper panel of Table 1 provides some idea of the actual change over time of some key budgetary categories, such as domestic revenue mobilization, public primary recurrent and investment spending, and net domestic borrowing. The "average" country data overall show that domestic revenue mobilization and primary recurrent spending increasing significantly in recent years, which is less the case for total investment spending; also net domestic borrowing has fallen in recent years. However, from this descriptive overview of the evolution of main recipient country budget aggregates, it is not at all clear to what extent this evolution over time is (partially or fully) caused by changes in the magnitude (fiscal space) and composition of aid. In order to assess the causal fiscal response effects of different categories of aid, and debt relief in particular, we have to rely on intertemporal fiscal response models, as will be discussed in the next section.

\footnotetext{
${ }^{5}$ These tracking mechanisms range from counterpart funds, to virtual funds over comprehensive budget tracking. See again IMF and IDA (2001) for an overview of different systems, and De Groot et al. (2003) for an application to five African HIPCs.

${ }^{6}$ Note that in order for this to happen, it implicitly assumes that donor and recipient government priorities differ. The PRSP logic is to increase country ownership, and as such, to minimize fungibility.
} 


\section{Modeling Fiscal Response Analysis of Aid and Debt Relief}

The theoretical framework underlying this study has become known as fiscal response modeling. The basic model is due to Heller (1975) and has been refined and extended by various authors over time ${ }^{7}$. The importance of recipient government conduct for aid effectiveness is implicit in the fiscal response literature. Fiscal response models try to look at the recipient government's response to aid flows, in terms of the decisions between various sources of revenues like taxation and domestic borrowing and areas of expenditures like public investment and recurrent government expenditure (Otim, 1996). These models view governments as rational agents that try to maximize the value of some ultimate target, like the rate of economic growth. Governments do this by steering certain policy variables to their desired levels. In practice, this is typically modeled as a quadratic loss function, which attains maximal utility if policy targets are met. This utility function is then optimized subject to the budget constraint that expenditures cannot exceed revenues. From this, a system of structural equations is derived, whose coefficients are usually estimated using non-linear three stage least squares (NL3SLS).

Even though the empirical application in the present paper is based on a formal model of government fiscal behavior, it is important to note, as in Osei et al. (2005), that "... fiscal response models are not predictive theories, in a sense that they do not generate specific testable hypotheses of the effects of aid on fiscal behavior. For example, fiscal response models do not predict that aid will increase investment spending or will reduce tax effort; aid is posited to have effects as fiscal variables are related, but in a manner that can only be determined empirically." (p. 1038). This is one of the reasons why the literature has evolved as case studies
Although the issue that fiscal response models are trying to address is interesting, the way this is usually done has been criticized on a number of grounds. Probably the most important criticism is of the need to come up with credible target variables for the intermediate policy variables, like government expenditure and revenue. It has been noted by Osei et al. (2005) that the estimates for the structural equations are sensitive to the way in which the targets are approximated. Also, White (1992) critically reviews fiscal response models. One of the shortcomings he notes is that there is no attempt to analyze the dynamic aspects of aid.

As a response to this criticism, Osei et al. (2005) make a case for using vector autoregessive (VAR) methods to estimate the fiscal response to aid (and apply it to the case of Ghana). A VAR is the multivariate extension of autoregressive moving average models (ARMA). It describes the dynamic evolution of a number of variables from their common history. Formally, if we consider two variables $\mathrm{Xt}$ and Yt, the VAR consists of two equations. The order of the VAR refers to the number of lags included in the system. Hence, a first order VAR would be given by:

$$
\begin{aligned}
& Y_{t}=\alpha_{1}+\beta_{11} Y_{t-1}+\beta_{12} X_{t-1}+\varepsilon_{1 t} \\
& X_{t}=\alpha_{2}+\beta_{21} Y_{t-1}+\beta_{22} X_{t-1}+\varepsilon_{2 t}
\end{aligned}
$$

The advantages of using VARs in the context of fiscal response models are well described in Osei et al. (2005). They argue that the situation of interrelated variables is particularly suited to estimation using a VAR approach, since it is

${ }^{7}$ See Cassimon and Van Campenhout (2006) and the references therein for an overview of the fiscal response literature and a formal presentation of the model. 
posited on there being a relationship between the variables in the system and lets the data reveal the nature of that relationship. Echoing Sims (1980) who advocates the use of VAR models instead of structural simultaneous equations models because the distinction between endogenous and exogenous variables does not have to be made a priori, and "arbitrary" constraints to ensure identification are not required, they point out that estimation of the reduced form is sufficient for their purpose. Indeed, in the context of fiscal response modeling, estimating VARs will eliminate the need to presume (and estimate) targets for the intermediate policy variables and accommodates the criticism that fiscal response models are too static. An additional advantage is that one can use impulse response functions to simulate the effect of injections of certain types of aid on other fiscal variables. So, in the present paper, we will also adopt a VAR approach.

However, we will not confine ourselves to studying one country, but use a panel of 24 African HIPC countries. The reason why we opt for a panel setup is because our main interest is in (the relative effectiveness of) debt relief. First of all, debt relief is a relatively new form of aid, and has become prominent only in the last years as the HIPC Initiative gained momentum. If we confined ourselves to country case studies there would be too little variance in the sample to come to meaningful estimates of its effects.
Second, and more importantly, we are also looking for fiscal response behavior that is common across African HIPCs (after controlling for country specific heterogeneity) as we also want to unravel the more "systemic" effect of a "global debt relief initiative" such as the HIPC. In doing so, we can contribute to the current policy debate focusing on the question of to what extent debt relief leads to more desirable fiscal response effects than other aid interventions, and, as a consequence of that, to what extent more international initiatives on debt relief might be warranted. However, again, we cannot make any hypothesis about the nature and size of the relationships, as this is an entirely empirical question.

Our panel VAR model will comprise nine variables. Five of these are aid instruments: project grants, program grants, project loans, program loans and debt relief. The other four variables are domestic government revenue (tax and nontax), government current primary expenditure, public investment and government domestic borrowing. We decided to look at the importance of each variable as a share of GDP. In doing so, we avoid introducing measurement error through improper deflation and currency conversion ${ }^{8}$. Our preferred specification, guided by formal criteria and degrees of freedom considerations, is a VAR with two lags, and includes country dummies to control for unobserved country heterogeneity. ${ }^{9}$

\footnotetext{
${ }^{8}$ Furthermore, it reduces the chance of ending up with non-stationary variables. Formal stationarity tests using the Levine-Lin-Chu (2002) panel unit root test show that all variables are stationary (available from the authors on request).

${ }^{9}$ It is well known that this estimator is not consistent for panels with large $\mathrm{N}$ and fixed $\mathrm{T}$. In such cases, dynamic panel data methods should be used, like for instance the Arellano-Bond estimator (Bond, 2002). However, since our panel has 15 years for 24 countries, we judged that the bias would probably be small. As a robustness check we also estimated the VAR using the Arellano-Bond system-GMM estimator (not reported here, available on request). Results were similar indeed. A more elaborate account of these issues can be found in Cassimon and Van Campenhout (2006).
} 


\section{An Application to African HIPC Countries}

The results of the VAR are presented in Table 2. For the most interesting variables (domestic revenue collection, current primary expenditure and investment expenditure), we also give graphical representations of the impulse response functions of our five aid instruments in figure 2 Furthermore, we include a graph of the effect of an increase in debt relief on the four other aid variables. We will discuss the results equation by equation.

The second column with heading total domestic revenue (tot dom rev) presents the fiscal response of government tax and non-tax collection. The first thing we note is the significant autoregressive effect of tax collection. Governments that collect more revenues than the average are likely to collect more revenues in the future as well. A second significant variable that affects revenue collection is government investment. As expected, better-than-average performers on investment will increase future revenue collection. Note however that this effect is not immediate, but occurs only after two years. The fact that countries have received project grants also seems to increase revenue collection. This is strange, since most other studies find that grants and local revenue collection are to a large extent substitutes. However, it should also be noted that the increase in revenue collection triggered by project grants is short lived: in the second year revenue collection bounces back by more than what it increased. The effect of loans is even more puzzling. Common sense would indeed suggest that an increase in loans would also increase government revenue collection, since the loans have to be paid back. We find, however, that governments respond to loans by lowering taxes. A possible explanation may be that two years is too short a time span to capture this payback effect. The variable of interest to us, debt relief, is also significant. However, its positive effect is only felt after two years.

Figure 2 panel (a) shows the impulse response functions associated with revenue collection. It represents the evolution over time of revenue collection due to a one standard deviation shock of the aid variable. For instance, we see that a shock in program grants increases domestic revenue collection after one period, but that it falls back to the original level in the next period. The third year following the shock revenue collection increases again. In the seventh year following the shock, the growth in revenue collection is at its maximum. For the variable we focus on, debt relief, the initial response is a (modest) increase in revenue already from the first year on, with the positive response increasing afterwards; the response is maximal in year 6, where tax and non-tax receipts increase by about 0.48 percent. All other aid modalities seem to reduce domestic revenue collection, except for a very short-lived initial increase for project grants and an even more short-lived one for program loans. 
Table 2. Estimation Results for Fiscal Response VAR model

\begin{tabular}{|c|c|c|c|c|c|c|c|c|c|}
\hline & $\begin{array}{c}\text { Total } \\
\text { Domestic } \\
\text { Revenue }\end{array}$ & $\begin{array}{c}\text { Current } \\
\text { Primary } \\
\text { Expenditure }\end{array}$ & $\begin{array}{l}\text { Investment } \\
\text { Expenditure }\end{array}$ & $\begin{array}{l}\text { Domestic } \\
\text { Financing }\end{array}$ & $\begin{array}{l}\text { Project } \\
\text { Grants }\end{array}$ & $\begin{array}{l}\text { Program } \\
\text { Grants }\end{array}$ & $\begin{array}{l}\text { Project } \\
\text { Loans }\end{array}$ & $\begin{array}{l}\text { Program } \\
\text { Loans }\end{array}$ & $\begin{array}{l}\text { Total } \\
\text { Debt } \\
\text { Relief }\end{array}$ \\
\hline L.tot dom rev. & $0.543^{* *}$ & $0.339^{* *}$ & $0.378^{*}$ & -0.187 & 0.090 & $0.245^{* *}$ & 0.037 & 0.058 & 0.024 \\
\hline L2.tot dom rev & -0.110 & $-0.224^{*}$ & -0.134 & -0.145 & -0.021 & -0.113 & $-0.160^{*}$ & $-0.160^{*}$ & 0.089 \\
\hline L.curr prim exp & 0.026 & $0.380^{* *}$ & -0.046 & -0.128 & 0.030 & 0.039 & $-0.185^{* *}$ & $-0.107+$ & $0.219^{* *}$ \\
\hline L2.curr prim exp & $0.141+$ & 0.119 & 0.006 & $0.353+$ & -0.062 & -0.035 & $0.294^{* *}$ & $0.141^{*}$ & $-0.217^{* *}$ \\
\hline L.invest exp & $-0.241^{* *}$ & 0.009 & -0.077 & 0.322 & $-0.152^{*}$ & 0.044 & -0.063 & -0.013 & 0.010 \\
\hline L2.invest exp & $0.416^{* *}$ & $0.259^{*}$ & $0.378^{*}$ & 0.307 & 0.043 & 0.004 & $0.147^{*}$ & $0.124+$ & 0.013 \\
\hline L.domestic fin & 0.041 & -0.041 & $0.117+$ & $-0.344^{* *}$ & $0.094^{* *}$ & $0.076^{*}$ & 0.046 & $0.075^{*}$ & -0.031 \\
\hline L2.domestic fin & $-0.155^{*}$ & $-0.129+$ & $-0.268^{* *}$ & -0.042 & 0.006 & -0.018 & $-0.250^{* *}$ & -0.061 & 0.060 \\
\hline L.proj grants & $0.411^{* *}$ & $0.302^{*}$ & $0.360+$ & -0.185 & $0.484^{* *}$ & -0.106 & -0.102 & $0.257^{* *}$ & -0.055 \\
\hline L2.proj grants & $-0.606^{* *}$ & $-0.531^{* *}$ & $-0.645^{* *}$ & $-0.563+$ & -0.108 & -0.151 & -0.063 & $-0.256^{* *}$ & -0.043 \\
\hline L.progr grants & 0.090 & -0.007 & 0.069 & -0.070 & 0.022 & $0.390^{* *}$ & 0.029 & -0.021 & $0.165^{\star}$ \\
\hline L2.progr grants & $-0.263^{*}$ & -0.061 & 0.264 & -0.178 & $0.217^{*}$ & $0.234^{*}$ & -0.007 & -0.015 & 0.016 \\
\hline L.proj loans & -0.112 & $-0.601^{* *}$ & $0.388^{*}$ & $-0.609^{*}$ & 0.089 & 0.009 & $0.747^{* *}$ & $-0.167+$ & $-0.270^{* *}$ \\
\hline L2.proj loans & -0.012 & -0.042 & -0.071 & 0.122 & -0.018 & -0.107 & $-0.378^{* *}$ & -0.102 & $0.197^{*}$ \\
\hline L2.prog loans & 0.125 & -0.181 & $-0.521^{* *}$ & -0.245 & $-0.167^{*}$ & -0.074 & $-0.261^{* *}$ & -0.035 & $-0.234^{* *}$ \\
\hline L.tot debt relief & 0.100 & 0.023 & -0.100 & -0.292 & $-0.206^{*}$ & $-0.207+$ & -0.102 & $-0.215^{*}$ & $0.426^{* *}$ \\
\hline L2.tot debt relief & $0.318^{* *}$ & $0.227+$ & 0.265 & $-0.831^{* *}$ & $0.186^{*}$ & 0.167 & -0.097 & 0.095 & 0.121 \\
\hline R-squared & 0.90 & 0.92 & 0.89 & 0.46 & 0.94 & 0.64 & 0.78 & 0.34 & 0.68 \\
\hline
\end{tabular}


The third column in Table 2 reports the response of government consumption (current primary expenditure, curr prim exp). As expected, countries that collected more taxes in the previous year have higher current primary spending. There is also a positive autoregressive effect. Governments that were high consumers in the past are likely to be high consumers in the future as well. There is weak evidence of a lagged positive effect of investment and a negative effect of net domestic borrowing. For grants, we only find significant effects for project grants. An increase in project grants in the previous year leads to an increase in government current expenditure. However, this effect is countered by a negative effect of project grants two periods before. We do not find a significant impact for program grants. Loans, be it project or program, generally tend to reduce government consumption. As for total revenue collection, debt relief is positive and significant, but only after two years.

The impulse response functions of government consumption are depicted in panel (b) of Figure 2. Again, the debt relief response is the largest (positive) one, from the first year on. It seems that debt relief is particularly "spent" as increased recurrent government expenditure. Also, program grants provoke a positive response, albeit only from the fourth year on (although this is based on non-significant coefficients). The impulse response function of project grants is also an interesting one. The first four years after a shock in this variable, government consumption rises. In subsequent years, the effect is negative. Shocks in loans, especially of the project type, tend to reduce government current primary expenditure.

The third variable is government investment (invest exp). Since this variable is often thought to be important in determining long run growth and poverty reduction, fiscal response studies usually attach great importance to its response to aid shocks. Table 2 shows that, as expected, an increase in revenue increases government investment. We also find a significant second order autoregressive effect. An increase in local borrowing reduces government investment, but only after two periods. For the aid variables, project grants initially increase investment, but the second order effect is negative and large. There is no strong support that program grants increase government investment.
For loans, we find the reverse: there is some indication that project loans push investment up, while program loans reduce investment. Finally, there is no strong sign that debt relief leads to higher investment, which is similar to the effect of program grants on government investment.

The impulse response functions in panel (c) of Figure 2 clearly show the positive effect of an increase in program grants. The only other aid variable that has an unambiguous positive effect on investment is debt relief, despite the initial dip after one year - as noted in the previous paragraph; however, this impulse response effect is based on non-significant coefficients (only significant at around 15\%). As mentioned also in the previous paragraph, project loans increase investment as well. However, this positive effect is short lived; after the third year following the shock, the effect becomes negative. Program loans, and to a lesser extent project grants, reduce government investment.

The fourth equation refers to domestic financing (domestic fin). We observe that government consumption increases domestic borrowing, albeit with a lag. It has a significant negative first order autoregressive component. Regarding the aid variables, we find that most of them reduce the need for the government to use domestic financing; these effects are most outspoken for program and project loans. But debt relief also reduces the need for local borrowing, even if the effect manifests itself only after two periods.

Columns six to ten in Table 2 are the equations for the aid variables. These equations reveal how different aid flows influence each other. For instance, we find significant first order autoregressive effects for project grants, program grants and especially for project loans, but not for program loans. Also, debt relief has a significant autoregressive component, which is not surprising due to the multi-year nature of the debt relief initiatives. We also find that countries that have received program loans in the past are likely to get fewer project grants in the future. Having received debt relief initially reduces the amount of most other aid variables, notably of project grants. However, after two years, there is a significant positive response of project grants to debt relief, less significantly so for program grants and loans. Program loans seem to reduce project grants 
and project loans, but for the latter we only find a significant second order effect. There is weak evidence that program loans respond negatively to project loans. An increase in program grants increases the chances of getting debt relief in the future, while countries that take up loans, be it project or program loans, are less likely to receive debt relief.

For the variable that is central to this study, debt relief, we present the impulse response function of a shock in debt relief on the other aid categories in Figure 2 - panel (d). There, it seems that a positive shock in debt relief initially lowers all other types of aid; however, after two years, grants (both project and program) increase again. For loans, both project as well as program, the initial negative effect takes more time to reverse; the effect on project loans becomes positive after about seven years and stays positive, while the effect of debt relief on program loans moves back to the negative. This provides some confirmation of both the initial donor fungibility as well as later additionality hypotheses.
Overall, we can conclude that the observed public finance response to debt relief is not so negative as some might worry about, especially when we compare them to the effects of other aid modalities. There are signs that debt relief does not reduce domestic resource mobilization, contrary to some other aid modalities, and manages to increase recurrent consumption and reduce domestic financing needs. No negative effect of debt relief on public investment is witnessed. And there is no lasting substitution effect of debt relief on other types of aid: after an initial substitution effect, debt relief provokes a positive response effect for most other types of aid, notably for program grants. Again compared to other aid modalities, the fiscal response effects of debt relief are most similar to those of program grants, which is not so surprising, considering the fact that they are very similar in nature. More particularly, however, the effects of debt relief are in general more positive than those of program grants, both on domestic resource mobilization and on recurrent primary consumption, and to a lesser extent (because of being non-significant) also on public investment.

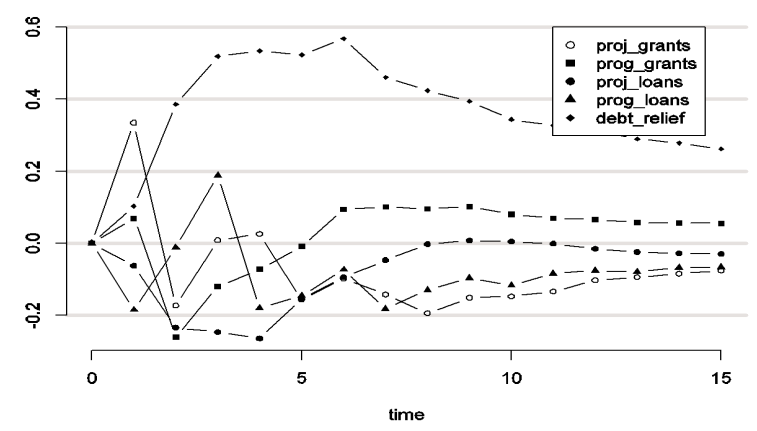

(c) effect of aid on government investment

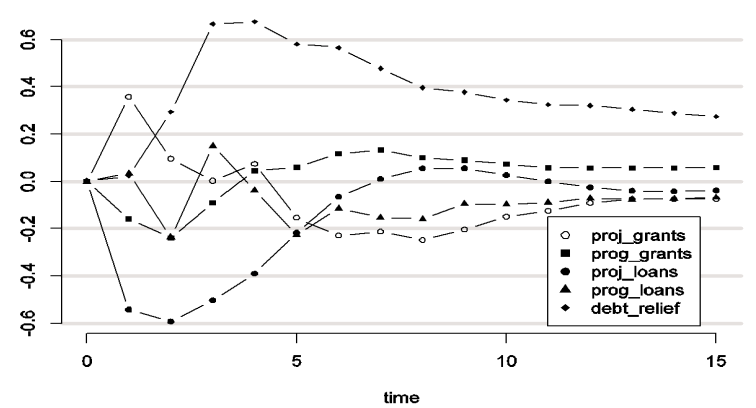

(d) effect of debt relief on other aid variables
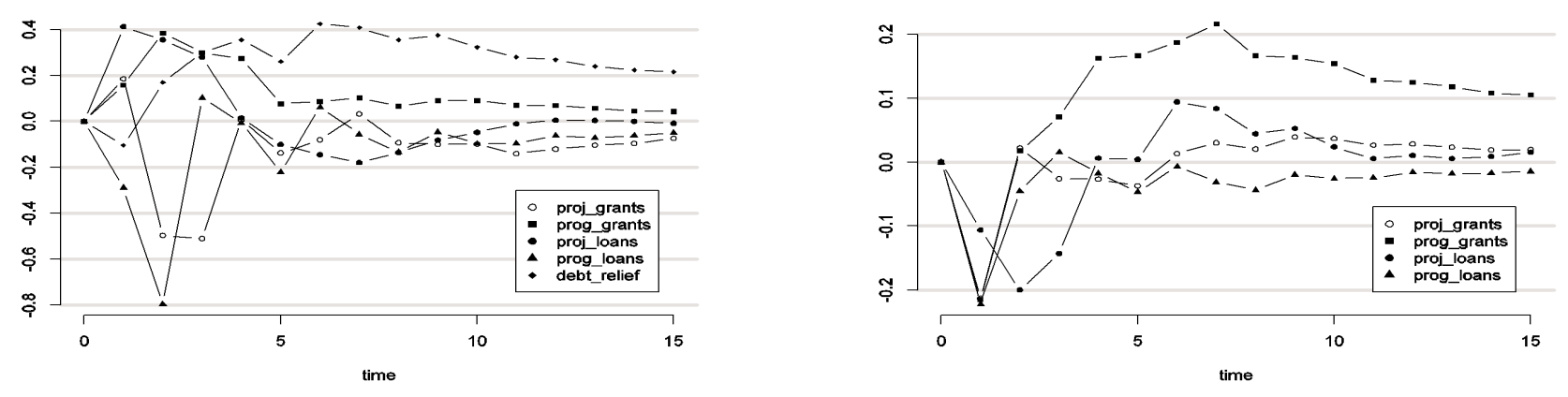

(C) AFD Working Paper $\mathbf{N}^{\circ} \mathbf{6 3}$ - Comparative Fiscal Response Effects of Debt Relief - an Application to African HIPCs 


\section{Conclusions}

During the last decades, debt relief has resurfaced in the aid debate. The main reason why this is so is probably because of the strong civil society support it currently gets, both in the North and in the South. But one should not forget that there are also solid economic arguments to be made in favor of debt reduction. However, if one sees debt relief as just another modality of aid delivery, one should look at its relative effectiveness, which is largely an empirical question.

In this paper, we have tried to add to the literature by looking at aid effectiveness from a fiscal (response) perspective. The paper also extends former analysis (Cassimon and Van Campenhout, 2006), not only by focusing on African HIPCs, but mainly by disaggregating aid further into their project and program (grant and loan) components, and by extending the time period of our analysis up to 2006, which also allows us to tentatively deal with the effect of MDRI debt relief.

It shows that the direct fiscal space effect of HIPC (and MDRI) debt relief is very limited, about $1.5 \%$ and $0.5 \%$ of GDP respectively. Moreover, this direct fiscal space effect might to some extent only materialize on an "accounting" basis: on average about two-thirds ( $1 \%$ of GDP) of the total HIPC effect is delivered in grant form, and this part can be considered a proxy for the real fiscal space effect. As such, one observes a lot of worries being echoed about the real fiscal (response) effects of debt relief, questioning the extent to which donor efforts on debt relief should be scaled up in the absence of these effects, especially when donor actions on debt relief should substitute for other types of aid interventions.

In response to these worries, our analysis finds no hard signs to confirm this doom scenario. On the contrary, the observed overall fiscal space effects of debt relief are relatively promising: there are no signs that debt relief crowds out domestic revenue collection. In contrast, governments seem to respond to debt relief by increasing tax and nontax collection. Also, for government current primary expenditure, debt relief is positive and significant. No clear signs are present that debt relief has a lasting influence on public investment, but this seems to be the case for most other aid modalities too. We also find that debt relief reduces the need for local borrowing, but the effect manifests itself only after two periods.

Moreover, our VAR model also provides some tentatively reassuring results on whether debt relief complements or substitutes for other aid, by showing initial donor fungibility to be overcompensated by additionality later, especially for program grants. Overall, we can conclude that the overall public finance response to debt relief is most similar to that of program grants, even outperforming it in some ways.

All in all, however, we should be cautious in using these tentative promising results in favor of debt relief in policy debate, e.g. to advocate for more debt relief. In order to validate this overall effect of debt relief, these "average" panel study effects should be confronted with more detailed country case studies. 


\section{References}

Berlage, L., D. Cassimon, J. Drèze and P. Reding (2003), "Prospective Aid and Indebtedness Relief: A Proposal”, World Development 31(10): 1635-1654.

Birdsall, N., S. Claessens and I. Diwan (2003), "Policy Selectivity Foregone: Debt and Donor Behaviour in Africa”, World Bank Economic Review 17(3): 409-435.

Bond, S.R. (2002), Dynamic Panel Data Models: A Guide to Micro Data Methods and Practice, CeMMAP Working Papers CWP09/02, Centre for Microdata Methods and Practice, Institute for Fiscal Studies.

Bulow, J. and K. Rogoff (1991), "Sovereign Repurchases: No Cure for Overhang", Quarterly Journal of Economics 106(4): 1219-1235.

Cassimon, D. and B. Van Campenhout (2006), Aid Effectiveness, Debt Relief and Public Finance Response: Evidence from a Panel of HIPC Countries, University of Antwerp, IOB Working Paper 2006-02. http://www.ua.ac.be/download.aspx?c=.IOBE\&n=37408\&ct=38185\&e=115146

De Groot, A., G. Jennes and D. Cassimon (2003), The Management of HIPC Funds in Recipient Countries: A Comparative Study of Five African Countries, Synthesis report, Study commissioned by the EC DG Development, ECORYS, Rotterdam.

Franco-Rodriguez, S., O. Morrissey, and M. McGillivray (1998), "Aid and the Public Sector in Pakistan: Evidence with Endogenous Aid", World Development 26(7): 1241-1250.

Heller, P.S. (1975), "A Model of Public Fiscal Behaviour in Developing Countries: Aid, Investment, and Taxation”, American Economic Review 65(3): 429-445.

Heller, P.S. (2005), Understanding Fiscal Space, IMF Policy Discussion Paper, No. PDP/05/4, IMF, Washington DC.

IMF \& IDA (2001) Tracking of Poverty-Reducing Public Spending in Heavily Indebted Poor Countries, IMF and IDA, Washington DC.

Krugman, P. (1988), "Financing vs. Forgiving a Debt Overhang”, Journal of Development Economics 29(3): $253-268$.

Levin, A., C.-F. Lin and J. Chu (2002), “Unit Root Tests in Panel Data: Asymptotic and Finite-sample Properties”, Journal of Econometrics 108(1): 1-24.

(C) AFD Working Paper $\mathbf{N}^{\circ} \mathbf{6 3}$ - Comparative Fiscal Response Effects of Debt Relief - an Application to African HIPCs 
McGillivray, M. and O. Morrissey (2000), "Aid Fungibility in Assessing Aid: Red Herring or True Concern?" Journal of International Development 12(3): 413-428.

McGillivray, M. and B. Ouattara (2005), "Aid, Debt Burden and Government Fiscal Behaviour in Côte d'Ivoire”, Journal of African Economies 14(2): 247-269.

Osei, R., O. Morrissey and T. Lloyd (2005), "The Fiscal Effects of Aid in Ghana", Journal of International Development 17(8): 1037-1053.

Otim, S. (1996), "Foreign Aid and Government Fiscal Behaviour in Low-income South Asian Countries", Applied Economics 28(8): 927-933.

Pack, H. and J.R. Pack (1993), “Foreign Aid and the Question of Fungibility”, Review of Economics and Statistics 75(2): $258-265$.

Sims, C.A. (1980), "Macroeconomics and Reality", Econometrica 48(1): 1-48.

Weeks, J. and T. McKinley (2006), Does Debt Relief Increase Fiscal Space in Zambia? The MDG Implications, UNDP, International Poverty Centre Country Study No.5.

White, H. (1992), "The Macroeconomic Impact of Development Aid: A Critical Survey", Journal of Development Studies 28(2): 163-240. 


\section{Série Documents de travail / Working Papers Series}

N 1 A Poverty Forecasting Tool: A Case-Study of Senegal

Thierry Latreille, AFD - Janvier 2005.

$\mathrm{N}^{\circ} 2 \quad$ Les OMD et l'aide de cinquième génération

Jean-David Naudet, AFD - Mai 2005.

$\mathrm{N}^{\circ} 3$ Biens publics mondiaux et développement: De nouveaux arbitrages pour l'aide?

Sarah Marniesse, AFD - Septembre 2005.

$\overline{N^{\circ} 4}$ Agir en faveur des acteurs et des sociétés fragiles. Pour une vision renouvelée des enjeux de l'aide au développement dans la prévention et la gestion des crises

Beyond the Fragile State: Taking Action to Assist Fragile Actors and Societies Jean-Marc Châtaigner et François Gaulme, AFD - Septembre 2005.

$\overline{N^{\circ} 5} \quad$ La filière riz au Mali : compétitivité et perspectives de marché Pierre Baris, Jean Zaslavsky, Serge Perrin - Septembre 2005.

$N^{\circ} 6$ Turquie : Risque systémique bancaire et vulnérabilités macro-financières François-Xavier Bellocq et Vincent Caupin, AFD - Octobre 2005.

$N^{\circ} 7 \quad$ La Tunisie et le marché euro-méditerranéen du tourisme Jean-Raphaël Chaponnière, CEPN et AFD et Marc Lautier, CARE, Université de Rouen - Septembre 2005.

N 8 Le développement, une question de chance ? A propos du rapport sur le développement dans le monde 2006 «Equité et Développement » Development, a Question of Opportunity? A Critique of the 2006 World Development Report:

Equity and Development Jean-Pierre Cling, Denis Cogneau, Jacques Loup, Jean-David Naudet, Mireille Razafindrakoto, François Roubaud, DIAL - Septembre 2005.

N 0 Aid Selectivity According to Augmented Criteria Jacky Amprou, AFD, Patrick Guillaumont, Sylviane Guillaumont Jeanneney, CERDI - Novembre 2005.

$\overline{N^{\circ} 10}$ Le Cambodge rural face à la pauvreté : contribution à la réflexion sur les dynamiques agraires et le changement social

Julien Calas, AFD Phnom-Penh - Janvier 2006.

$\overline{N^{\circ} 11}$ Vietnam : les vulnérabilités macro-financières associées au processus d'émergence. Vietnam: Macro-Financial Vulnerabilities Associated with the Emergence Process François-Xavier Bellocq et Jean-Raphaël Chaponnière, AFD - Janvier 2006.

$\mathrm{N}^{\circ} 12$ Chine : la croissance et ses déséquilibres François-Xavier Bellocq et Jean-Raphaël Chaponnière, AFD - Janvier 2006.

$\overline{N^{\circ} 13}$ Legs colonial et gouvernance contemporaine (Note de synthèse) Jean-François Bayart, Romain Bertrand, Thornike Gordadze, Béatrice Hibou et Françoise Mengin, FASOPO (Fonds d'analyse des sociétés politiques) - Mars 2006.

(C) AFD Working Paper $\mathbf{N}^{\circ} \mathbf{6 3}$ - Comparative Fiscal Response Effects of Debt Relief - an Application to African HIPCs 
$\overline{N^{\circ} 14}$ Apprendre pour vivre et travailler : contribution du GEFOP au Rapport sur le développement dans le monde 2007 de la Banque mondiale Learning for Life and Work : GEFOP Contibution to the World Developement Report 2007 Réseau GEFOP (Synthèse rédigée par R. Walther) - Mars 2006.

$\mathrm{N}^{\circ} 15$ La formation professionnelle en secteur informel (Note de problématique) Vocational Training in the Informal Sector - Issue Paper Richard Walther, consultant ITG - Mars 2006.

$\mathrm{N}^{\circ} 16$ La formation professionnelle en secteur informel - Rapport sur l'enquête terrain au Maroc Vocational Training in the Informal Sector - Report on the Morocco Field Survey Richard Walther, consultant ITG - Juin 2006.

$\overline{N^{\circ} 17}$ La formation professionnelle en secteur informel - Rapport sur l'enquête terrain au Cameroun Vocational Training in the Informal Sector - Report on the Cameroon Field Survey Richard Walther, consultant ITG, avec le concours d'Ewa Filipiak et de Christine Uhder, AFD - Juillet 2006.

$\overline{N^{\circ} 18}$ Rapport sur le risque-pays du Maroc Jérôme Sgard, Cepii et Université de Paris-Dauphine - Juin 2006.

$\overline{N^{\circ} 19}$ La formation professionnelle en secteur informel - Rapport sur l'enquête terrain au Bénin Vocational Training in the Informal Sector - Report on the Benin Field Survey Richard Walther, consultant ITG, avec le concours d'Ewa Filipiak et de Christine Uhder - Juillet 2006.

$N^{\circ} 20$ Institutions, développement et pauvreté Institutions, Development and Poverty Alice Sindzingre, CNRS, EconomiX, Université Paris X-Nanterre ; School of Oriental and African Studies (SOAS), Université de Londres - Juillet 2006.

No21 La formation professionnelle en secteur informel - Rapport sur l'enquête terrain au Sénégal Vocational Training in the Informal Sector - Report on the Senegal Field Survey Richard Walther, consultant ITG, avec le concours d'Ewa Filipiak et de Christine Uhder - Juillet 2006.

$\mathrm{N}^{\circ} 22$ Les fondations philanthropiques américaines, acteurs émergents de la mondialisation et piliers du dialogue transatlantique.

American Philantropic Foundations: Emerging Actors of Globalization and Pillars of the Transatlantic Dialog Benoît Chervalier, German Marshall Fund of the United States, et Joseph Zimet, AFD - Juillet 2006.

$N^{\circ} 23 \quad$ L'AFD et ses partenaires : La dimension culturelle Philippe d'Iribarne, CEREB - CNRS - Août 2006.

N²4 Secteur de l'eau au Sénégal - Un partenariat équilibré entre acteurs publics et privés pour servir les plus démunis ?

Aymeric Blanc, département de la Recherche, AFD, et Cédric Ghesquières, consultant junior, AFD - Août 2006.

$\overline{N^{\circ} 25}$ Décentralisation et politique de l'eau gratuite en Afrique du Sud: Quelle place pour le secteur privé ? Vocational Training in the Informal Sector - Report on the Senegal Field Survey

Aymeric Blanc, département de la Recherche, AFD, et Cédric Ghesquières, consultant junior, AFD - Août 2006.

$\mathrm{N}^{\circ} 26$ L'intégration des programmes d'aide alimentaire aux politiques de développement du Niger : le cas de la crise alimentaire 2004-2005.

The Integration of Food Aid Programmes in Niger's Development Policies: the 2004-2005 Food Crisis Dorothée Chen et Nicolas Meisel, département de la Recherche, AFD, en partenariat avec DIAL - Septembre 2006. 
$\overline{N^{\circ} 27}$ Proposition d'organisation des outils de gestion du risque de marché au bénéfice des filières cotonnières africaines Jean Cordier, Agrocampus Rennes - Septembre 2006.

$\overline{N^{\circ} 28}$ Les privatisations en zone franc - synthèse des travaux du groupe de travail MINEFI/AFD Aymeric Blanc, département de la Recherche, AFD - Septembre 2006.

$\mathrm{N}^{\circ} 29$ Out of the financing trap? Financing post-conflict countries and LICUSs Marc Raffinot, Université-Dauphine, et Christine Rosellini, DIAL, Paris - Octobre 2006.

$\overline{N^{\circ} 30}$ La formation professionnelle en secteur informel - Rapport sur l'enquête terrain en Afrique du Sud Vocational Training in the Informal Sector - Report on the South Africa Field Survey

Richard Walther, ITG Consultant, Ewa Filipiak, département de la Recherche, AFD, et Christine Uhder, AFD Octobre 2006.

No 31 The Brain Drain: What Do We Know?

Frédéric Docquier, FNRS and IRES, Université Catholique de Louvain and World Bank - Khalid Sekkat, DULBEA, Université Libre de Bruxelles - Octobre 2006.

$\mathrm{N}^{\circ} 32$ Les délocalisations françaises vers la Turquie Julien Gourdon, CERDI, Université d'Auvergne - Décembre 2006.

$\mathrm{N}^{\circ} 33$ Capital naturel et développement durable en Afrique Natural Capital and Sustainable Development in Africa

Pierre-Noël Giraud, CERNA, Centre de recherche en économie industrielle, Ecole nationale supérieure des Mines de Paris, Denis Loyer, AFD - Décembre 2006.

$\mathrm{N}^{\circ} 34$ La formation professionnelle en secteur informel Rapport sur l'enquête terrain en Ethiopie Vocational Training in the Informal Sector - Report on the Ethiopia Field Survey

Richard Walther, Consultant ITG - Novembre 2006.

$\mathrm{N}^{\circ} 35$ La formation professionnelle en secteur informel Rapport sur l'enquête terrain en Angola Vocational Training in the Informal Sector - Report on the Angola Field Survey Richard Walther, Consultant ITG - Novembre 2006.

$N^{\circ} 36$ Les accords de partenariat économique : des accompagnements nécessaires Economic Partnerships Agreements: Accompanying Measures Are Needed Anna Lipchitz, département de la Recherche, AFD - Janvier 2007.

$N^{\circ} 37$ Energie du Mali, ou les paradoxes d'un « échec retentissant » Béatrice Hibou, CNRS - CERI, Olivier Vallée, Consultant, AFD - Janvier 2007.

$\overline{N^{\circ} 38}$ Public Private Partnerships in Water and Electricity in Africa Emmanuelle Auriol, ARQADE and IDEI Toulouse Sciences Economiques, Aymeric Blanc, département de la Recherche, AFD - Janvier 2007.

N 39 Economic Partnership Agreements and Regional Trade Flow Dynamics: The ECOWAS Case Benoît Faivre Dupaigre, Vanessa Alby-Flores, Borgui Yerima, Ann Vourc'h, Anna Lipchitz, Philippe Chedanne - Mars 2007.

$\overline{N^{\circ} 40} \quad$ La Régie des eaux de Phnom Penh : un modèle de gestion publique efficace Aymeric Blanc et Alain Riès, département de la Recherche, AFD - Mai 2007.

$N^{\circ} 41 \quad$ Répartition des gains dans les partenariats public-privé : effets comparés des modalités d'assiette d'une redevance de concession

Olivier Ratheaux, AFD - Juin 2007.

$\mathrm{N}^{\circ} 42$ Potential Financial Frameworks for a Sustainable UNEO Helle Husum, COWI, Erik Brander, COWI, Suzanne A.K. Steensen, COWI, et Emmanuelle Lachaussée, AFD - Juin 2007

( AFD Working Paper $\mathbf{N}^{\circ} \mathbf{6 3}$ - Comparative Fiscal Response Effects of Debt Relief - an Application to African HIPCs 
$\overline{N^{\circ} 43}$ La concession des aéroports de Madagascar : une privatisation en trompe-l'œil ? Aymeric Blanc, département de la Recherche, AFD, et Olivier Gouirand, AFD - Août 2007.

$\mathrm{N}^{\circ} 44$ La concession du chemin de fer du Cameroun : les paradoxes d'une réussite impopulaire Aymeric Blanc, département de la Recherche, AFD, et Olivier Gouirand, AFD - Août 2007.

$N^{\circ} 45 \quad$ Analyse rétrospective de la crise alimentaire au Niger en 2005 Jean-Pierre Olivier de Sardan, LASDEL, avec la participation de M. Ali Bako, E. Guillermet, O. Hamani, Y. Issa, M. Koné et M. Moha - Septembre 2007.

$N^{\circ} 46$ Une nouvelle base de données institutionnelles : «Profils Institutionnels 2006 » A new institutional database: «Institutional Profiles 2006 » Nicolas Meisel, département de la Recherche, AFD et Jacques Ould Aoudia, DGTPE - Septembre 2007

N ${ }^{\circ} 47$ Governance of Renewable Natural Resources: Concepts, Methods and Tools Sheila Wertz-Kanounnikoff, Institut du développement durable et des relations internationales (Iddri) et Dominique Rojat, AFD - Septembre 2007.

$\overline{N^{\circ} 48}$ La crise de la filière coton : conséquences économiques et financières au Burkina Faso François Xavier Bellocq et Arthur Silve, Département de la Recherche, AFD - Septembre 2007.

$\mathrm{N}^{\circ} 49 \quad$ Youth and labour market in Africa (DIAL) Jean-Pierre Cling, Flore Gubert, Christophe J. Nordman, Anne-Sophie, DIAL - Octobre 2007.

$\overline{\mathrm{N}^{\circ} 50}$ Culture and development: a review of literature. The continuing tension between modern standards and local contexts

Hèla Yousfi, Researcher at "Gestion et société", CNRS, Paris - November 2007.

№51 Transferts et déséquilibres macroéconomiques des économies ultramarines Philippe Jean-Pierre, université de la Réunion - Novembre 2007.

$\mathrm{N}^{\circ} 52$ Eloignement, insularité et compétitivité dans les petites économies d'outre-mer Bernard Poirine, maitre de conférences d'économie à l'université de la Polynésie française - Novembre 2007.

$\overline{N^{\circ} 53}$ Pourquoi s'ouvrir ? Contraintes et perspectives pour les économies ultramarines Jean-Michel Salmon, maitre de conférences, CEREGMIA-faculté de droit et d'économie de la Martinique, université des Antilles et de la Guyane et consultant indépendant à STRADEVCO - Novembre 2007.

№54 Regional Trade Agreements and Developing Countries: The Case of the Independent Pacific Island States Robert Scollay - November 2007.

№5 Corporate Social Responsibility in Turkey: Overview and Perspectives Naïg Cozannet, Agence Française de Développement, Helge Rieper, Frankfurt School of Management and FinanceYekbun Gurgoz, Agence Française de Développement - December 2007.

$N^{\circ} 56$ allocation geographique de l'apd francaise : Comparaison entre la sélectivité de l'APD française totaleet celle de l'Agence Française de Développement Jacky Amprou, AFD, Carl Bernadac, AFD, Pascaline Magnes, ministère des Affaires étrangères - Novembre 2007.

$\overline{N^{\circ} 57} \quad$ L'aide au commerce dans les pays en développement : des articulations complexes pour une efficacité réelle Marilyne Huchet-Bourdon, maître de conférences en économie, Agrocampus Rennes, Anna Lipchitz, économiste, département de la Recherche, AFD, Audrey Rousson, consultante, AFD - Janvier 2008.

$\overline{N^{\circ} 58}$ La « bonne gouvernance » est-elle une bonne stratégie de développement?

Is "Good Governance" a Good Development Strategy?

Nicolas Meisel, département de la recherche, AFD, Jacques Ould Aoudia, Direction Générale du Trésor et de la Politique, Economique du Ministère de l'Economie, des Finances et de l'Emploi - Janvier 2008. 
$N^{\circ} 59$ Prospective et enjeux énergétiques mondiaux - Un nouveau paradigme Bernard Laponche, consultant - Janvier 2008.

$\overline{N^{\circ} 60} \quad$ Cycle du crédit et vulnérabilités financières : évolutions récentes dans certains pays émergents Matteo Mogliani, Ecole d'économie de Paris - Mars 2008.

N61 L'industrie égyptienne depuis le début des années 1970 : histoire d'un développement contrarié Hélène Djoufelkit-Cottenet, département de la Recherche, AFD - Mars 2008.

$\overline{N^{\circ} 62}$ Africa and its Demographic Challenges: an Uncertain Future

Patrice Vimard, Institut de recherche pour le développement (IRD) - April 2008. 